Sains Malaysiana 49(4)(2020): 801-808

http://dx.doi.org/10.17576/jsm-2020-4904-09

\title{
Meibomian Gland Dropout and Ocular Surface Appearances of Young Adults in Kuala Lumpur
}

(Kehilangan Kelenjar Meibomian dan Ciri Permukaan Okul Dewasa Muda di Kuala Lumpur)

\author{
Mohamad Hanif Hajar Maidin, Bariah Mohd-Ali*, Zainora MoHAmmed \& JAMAludin MoHAmed
}

\begin{abstract}
Meibomian gland dropout (MGDo) refers to partial or total loss of the acinar tissues which can be detected by meibography. It is possible that MGDo can be associated with lid margin inflammation commonly seen in dry eye (DE) patients. This study evaluated the MGDo and its association with lid margin inflammation in young adults using meibography and lid wiper epitheliopathy (LWE) techniques. Other ocular surface appearance (cornea, conjunctiva and limbus) were also examined. A total of 107 healthy noncontact lens wearers were evaluated (mean age: $23.06 \pm 2.63$ years old). All subjects were screened with McMonnies Dry Eye Questionnaire (MDEQ) before undergoing clinical investigations using slit-lamp biomicroscope, LWE and meibography. Cornea, conjunctiva and limbus appearances were graded using the Efron grading scale. Following the MDEQ score, 36 subjects were classified as DE (mean 16.49 \pm 1.74 ), and 71 subjects were classified as non-DE (NDE, mean score: $7.23 \pm 3.09)$. The difference in corneal staining between both groups was significant $\left(\chi^{2}[1, N=107]=18.01, p<0.05\right)$. A total of $70 \%$ of subjects had LWE staining which was more apparent in subjects with $D E\left(\chi^{2}[1, N=107]=13.17, p<0.01\right)$. The meiboscore indicated that $44.85 \%$ of subjects had MGDo, with a higher percentage $(72.22 \%)$ in DE. There were significant differences between meiboscore in both groups $\left(\chi^{2}[1, N=107]=16.42, p<0.05\right)$. However, there was weak and insignificant correlation between LWE and meiboscore ( $r s=0.14, p=0.16)$. Positive correlations were noted between MDEQ and LWE $\left(r_{s}=\right.$ $0.49, p<0.01), M D E Q$ and corneal staining $\left(r_{s}=0.36, p<0.01\right)$ and MDEQ and meiboscore $\left(r_{s}=0.24, p<0.05\right)$. The results of this study demonstrated the differences in MGDo, LWE and ocular surface appearances between DE and NDE of the young adults but MGDo was not associated with LWE. Larger number of subjects is needed to confirm these findings.
\end{abstract}

Keywords: Adults; conjunctiva; cornea; Meibomian glands

\section{ABSTRAK}

Kehilangan kelenjar meibomian (MGDo) merujuk kepada kehilangan sepenuhnya atau sebahagian daripada tisu asinar yang boleh diukur menggunakan meibografi. Terdapat kemungkinan MGDo berkait dengan inflamasi margin kelopak mata yang kerap dilihat dalam kalangan pesakit mata kering (DE). Kajian ini mengkaji hubungan MGDo dengan inflamasi margin kelopak mata populasi dewasa muda menggunakan teknik meibografi dan lid wiper epitheliopathy (LWE). Penampilan permukaan okul yang lain turut dikaji. Seramai 107 bukan pemakai kanta sentuh (min umur: $23.06 \pm 2.63$ tahun) telah disaring menggunakan soalan kaji selidik McMonnies (MDEQ) sebelum menjalani pemeriksaan klinikal menggunakan lampu celah biomikroskop, lid wiper epitheliopathy (LWE) dan meibografi. Keadaan kornea, konjunktiva dan limbus digred menggunakan skala penggredan Efron. Seramai 36 orang subjek dikelaskan sebagai DE (min skor: 16.49 \pm 1.74 ) dan 71 orang sebagai NDE (min skor: $7.23 \pm 3.09$ ). Analisis menunjukkan perbezaan penandaan kornea yang signifikan antara kedua kumpulan $\left(\chi^{2}[1, N=107]=\right.$ $18.01, p<0.05)$. Seramai $70 \%$ subjek mempunyai penandaan LWE, lebih jelas pada subjek DE $\left(\chi^{2}[1, N=107]=\right.$ 13.17, $p<0.01)$. Meiboscore menunjukkan 44.85\% subjek mengalami kekurangan kelenjar, dengan peratusan yang lebih tinggi (72.22\%) pada subjek DE. Terdapat perbezaan signifikan meiboscore dalam dua kumpulan kajian $\left(\chi^{2}[1, N=107]=16.42, p<0.05\right)$, tetapi tiada korelasi didapati antara Meiboscore dan LWE $\left(r_{s}=0.14, p=0.16\right)$. Korelasi positif dilihat antara skor MDEQ dan LWE $\left(r_{s}=0.49, p<0.01\right)$, skor MDEQ dan penandaan kornea $\left(r_{s}=\right.$ $0.36, p<0.01)$ dan antara skor MDEQ dan meiboscore $\left(r_{s}=0.24, p<0.05\right)$. Keputusan kajian ini menunjukkan perbezaan MGDo, LWE dan penampilan permukaan okul antara DE dan NDE serta tiada hubungan antara MGDo dan LWE. Walau bagaimanapun, bilangan subjek yang lebih ramai diperlukan untuk mengesahkan hasil kajian ini.

Kata kunci: Dewasa; konjuntiva; kornea; kelenjar meibomian 


\section{INTRODUCTION}

The International Dry Eye Workshop in 2017 defined dry eye (DE) as multifactorial disease of the ocular surface characterized by a loss of homeostasis of the tear film, and accompanied by ocular symptoms, in which tear film instability and hyperosmolarity, ocular surface inflammation and damage, and neurosensory abnormalities play etiological role (Craig et al. 2017). The new definition brings new connotation as hyperosmolarity is a common indicator of DE including for aqueous deficiency dry eye (ADDE) and evaporative dry eye (EDE). This followed by changes in ocular surface and ocular symptoms while there are possible pathways to be explored as the etiological role.

Healthy meibomian gland secretes oily meibum that becomes a part of the tear lipid layer which is a physical barrier that slows down aqueous tear evaporation. The suboptimal function of meibomian gland, namely, meibomian gland dysfunction (MGD), is the main cause for EDE (Schaumberg et al. 2011). The International Workshop on Meibomian Gland Dysfunction defined MGD as a chronic, diffuse abnormality of the meibomian glands commonly characterized by terminal duct obstruction and/or qualitative/quantitative changes in glandular secretion. These changes may result in an alteration of the tear film, symptoms of eye irritation, clinically apparent inflammation, and ocular surface disease (Nelson et al. 2011).

Hyposecretion of tears refer to condition where reduction of meibum secretion caused by the surface blockage. Histopathology data from Korb and Henriquez (1980) and Nicolaides et al. (1989) showed narrowing of gland duct lead to blockage of meibomian gland orifice. In vivo observation of meibomian gland silhouette by infrared illumination and photography, known as meibography showed morphological changes on gland narrowing and gland loss in patients with clinical signs of MGD (Robin et al. 1985). The complete or partial loss of the acinar tissue when detected by meibography is known as Meibomian gland dropout (MGDo) (Shimazaki et al. 1995). Previous studies have indicated that MGDo increases with age in a normal population, not necessarily in response to the presence of obstructive MGD (Tomlinson et al. 2011). It is possible that MGDo can alter lipid secretion that is frequently associated with lid margin inflammation commonly seen in MGD patients (Nelson et al. 2011). Recently Viet Vu et al. (2018) showed the association between MGD and friction related diseases (FRD) on the severity of DE disease. The friction related diseases included keratoconjunctivitis and lid wiper epitheliopathy (LWE).

Asian population DE based research, such as in Shihpi, Taiwan (Lin et al. 2003), Chiba, Japan (Uchino et al. 2006) and Beijing, China (Jie et al. 2009), showed that the MGD prevalence is approximately $60 \%-68 \%$ in Asians which is much higher than prevalence for Caucasian that is $3.5 \%$ in Salisbury eye project (Schein et al. 1997) and approximately 20\% in Melbourne Visual Impairment Project (McCarty et al. 1998). Craig et al. (2016) investigated the influence of eyelid shape to ocular surface characteristics and DE symptoms between Asians and Caucasians and demonstrated higher degree of MGD in Asian population, which potentially predisposing them to DE problems.

The prevalence of DE in Malaysian population is around 15\% (Jamaliah et al. 2002; Mohd Ali et al. 2011). Earlier studies have showed that Malaysians have lower average tear stability than established values reported for Caucasian populations (Mohidin \& Ramli 2004; Mohidin et al. 2002), which is probably associated with MGDo and LWE. This study investigated MGDo and its association with lid margin inflammation in young adults using meibography and lid wiper epitheliopathy (LWE) techniques. Other ocular surface appearance (cornea, conjunctiva and limbus) were also examined.

\section{MATERIALS AND METHODS}

This is a cross-sectional study using cluster sampling method. Participants were screened using selfadministrated McMonnies Dry Eye Questionnaire (MDEQ). The questionnaire consists of 12 questions that focus on the clinical risk factors of DE. The questions use answer options with a weighted scoring scale and the total score can vary from 0 to 45 with 14.5 as the diagnostic score (McMonnies et al. 1998). MDEQ is relatively popular amongst local eye care practitioners and have been used in several studies by using local subjects (Ahmad et al. 2017; Mohammed et al. 2012; Mohd Ali et al. 2011).

This study was conducted at the Optometry Clinic, Faculty of Health Sciences, Universiti Kebangsaan Malaysia (UKM), Kuala Lumpur. The sample size was calculated using G*Power version 3.1.9.3 (Heinrich Heine University Düsseldorf, Germany) for comparison between two groups with two tailed test. The statistical test power was set at 0.8 , significant level at $p=0.05$, and the ratio between both groups were set at 0.5 with a medium effect size (Faul et al. 2007). The total sample size required was 100, with 34 subjects with DE and 66 with NDE. To ensure a sufficient number of subjects, advertisements were placed on bulletin boards around the campus. The inclusion criteria included those with age between 19 and 30 years old, had never worn contact lens before, free from any ocular disease and systemic illness and not pregnant or smoking during the time of study. This study was approved by UKM Medical Ethics Committee (NN-115-2013) and followed the tenets of Declaration of Helsinki on the use of human subjects in research.

All subjects were left to adapt to the clinical environment for approximately $10 \mathrm{~min}$ before any measurements were taken. This was a single blind study where the investigator did not know whether the subjects were DE or NDE before the measurements were taken. 
All clinical measurements were taken by 1 investigator in the same room with a temperature between $23{ }^{\circ} \mathrm{C}$ and $25{ }^{\circ} \mathrm{C}$ and humidity level between $45 \%$ and $50 \%$. Slit lamp examination was conducted to examine the bulbar conjunctiva and limbal redness and corneal staining before grading them following the Efron grading scale (Efron et al. 2011). The Efron grading scale is one of the most widely used grading scale by Optometrists to describe ocular surface changes related to contact lens wear (Brea et al. 2016). The scale consists of 5 images, labelled from 0 to 4 . Level 0 presents a perfectly white eye while level 4 indicates severe ocular problems. The investigators have to look for the grade of the scale that is most similar to the patient's eye. The whole structure of interest is observed using slit lamp biomicroscope under high and/or low magnification as required and the grading is estimated to the nearest scale unit.

The cornea was later stained with $2 \%$ fluorescein (Contacare, Gujarat, India), and sequential staining was conducted using 1\% lissamine green (Contacare, Gujarat, India) to detect LWE. Lid area images were captured using the digital camera DC-1 (Topcon, Tokyo, Japan) which was attached to the slit lamp Topcon SL-7 (Topcon, Tokyo, Japan). The LWE was graded as follows Korb et al. (2005)

Non-contact meibography was used to examine the meibomian gland status. The modified near focused CCTV camera Neo V NR-107 (AG Neovo, San Joe, CA USA) was connected to a laptop (Apple, CA, USA) with Easy CAP USB 2.0 (DC60-202, China) adaptor which converts analogue video signals into digital inputs and records on Easy CAP Viewer software for Mac OS (version 0.62, Easy CAP Ltd, China). Daylight sensor on the camera was covered to activate night camera mode with infrared light on, and the infinity focus was adjusted to $5 \mathrm{~cm}$. Then, a still photo was obtained from the video recording and later inspected for meibomian gland dropout proportion to the lid area. The meibomian gland status was graded following the method of Arita et al. (2008), as follow: Grade 0 has no partial or missing glands, grade 1 indicates gland loss of less than $1 / 3$, grade 2 indicates gland loss from $1 / 3$ to $2 / 3$, and grade 3 indicates the loss of more than $2 / 3$. The number of glands from upper lids was observed and compared between two groups.

All data were analysed using the statistical package SPSS version 23.0 for MacOS (IBM Corp, Armonk, NY, USA). A p $<0.05$ was used as a level of significance. The normality of the data was confirmed with Shapiro-Wilk test. Mann-Whitney U test was used for comparison between subjects with DE and NDE. Chi-squared test was used to determine the association between two categorical data, and Spearman's rho correlation was applied to determine the relationship amongst the variables.

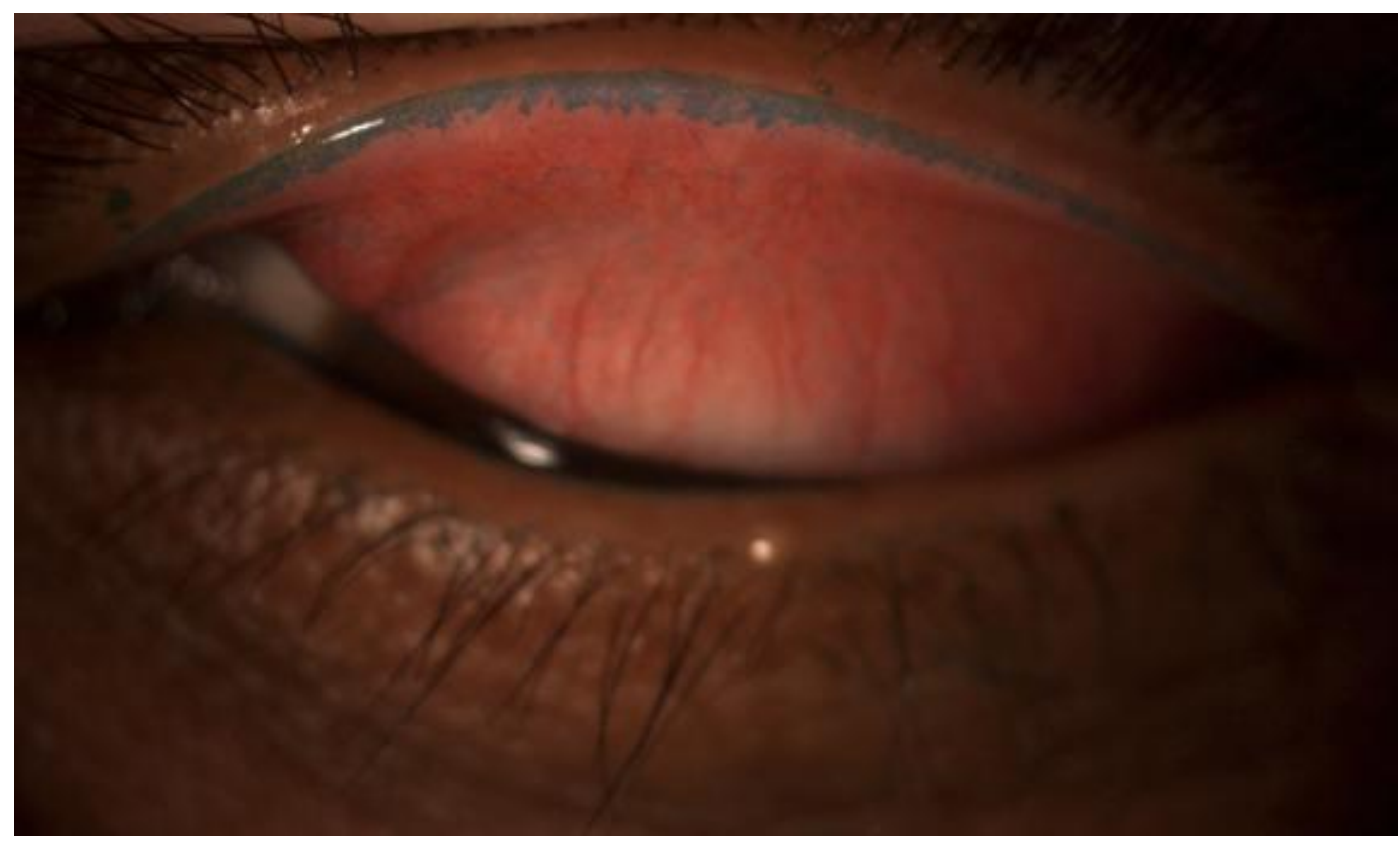

Рното 1. Lid Wiper Epitheliopathy (LWE) of upper eyelid stained using lissamine green 


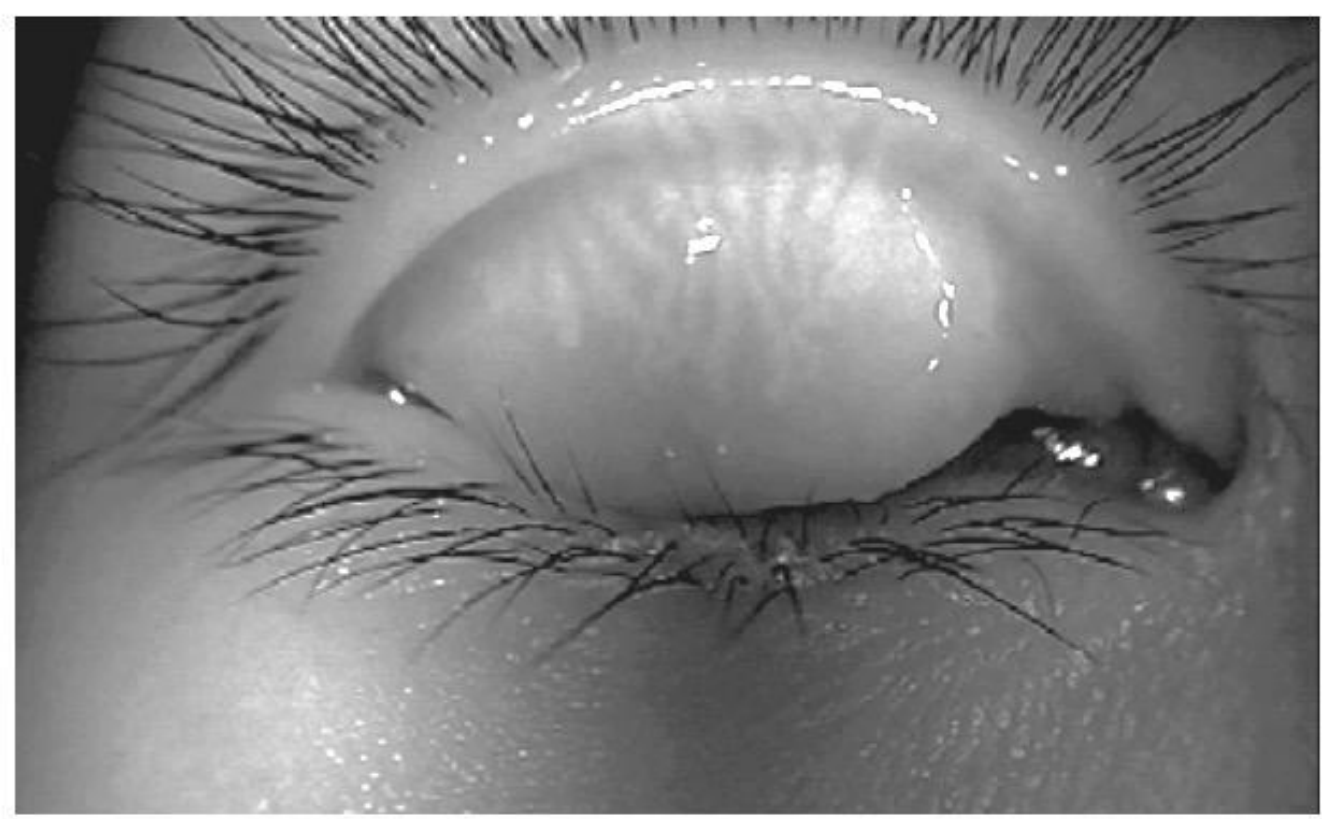

Рното 2. Meibography of the upper eyelid

\section{RESULTS}

A total of 107 subjects ( 72 females, 35 males) were recruited in this study. All subjects were screened using MDEQ, 36 of which scored higher, and the rest scored lower than the diagnostic score of 14.5. The mean MDEQ score for the DE group was $16.43 \pm 1.75$, and the mean for the NDE group was $7.69 \pm 3.09$. The mean age for DE was $23.06 \pm 3.32$ years old, and that for NDE with 23.14 \pm 2.31 years old. Table 1 summarises the demographical data of the subjects.

Conjunctival redness was observed in $77.77 \%$ (28 of 36) of subjects with mean grade of $1.46 \pm 0.60$ in the DE subjects and in $60 \%$ (43 of 71) of NDE subjects with mean grade of $1.17 \pm 0.49$. Following Efron grading scale, more than $50 \%$ of subjects had grades 1 and 2 for conjunctival redness. Limbal redness was observed in $30.55 \%$ of DE subjects with mean grade of $0.78 \pm$ 0.49 and $22.53 \%$ of NDE subjects with mean grade of $0.62 \pm 0.43$. The differences in conjunctiva redness $\left(\chi^{2}\right.$ $[1, \mathrm{~N}=107]=4.82, \mathrm{p}=0.09)$ and limbal redness $\left(\chi^{2}[1\right.$, $\mathrm{N}=107]=1.44, \mathrm{p}=0.23)$ were insignificant between both groups. Nevertheless, extrapolation analysis with Mann-Whitney U test indicated a significant difference in conjunctival redness $(\mathrm{p}<0.05)$ but not in limbal redness $(\mathrm{p}=0.11)$.

Corneal fluorescein staining was observed in $27.77 \%$ (10 out of 36) of DE subjects and 1.43\% (1 of 71) of subjects with NDE. Analysis using Chi-squared test showed significant difference between the two groups $\left(\chi^{2}\right.$ $[1, \mathrm{~N}=107]=18.01, \mathrm{p}<0.05)$. LWE staining was present in both groups with different proportions. Majority of DE subjects had higher LWE grading than subjects with NDE. Analysis using Chi-squared test showed significant difference between the two groups $\left(\chi^{2}[1, \mathrm{~N}=107]=\right.$ 13.17, $\mathrm{p}<0.05)$.

The meiboscore results are shown in Tables 4 and 5 . The mean numbers of meibomian glands observed in subjects with DE and NDE were $22.50 \pm 1.23$ and 22.34 \pm 1.50 , respectively. Analysis using Mann-Whitney U test showed insignificant difference between the two groups $(\mathrm{p}=0.38)$. The glands dropout severity in majority of subjects was lower than grade 3. Analysis using Chisquared test showed significant difference between both groups $\left(\chi^{2}[1, \mathrm{~N}=107]=16.42, \mathrm{p}<0.05\right)$.

The Spearman correlation was used to analyse the correlation between symptom score with meibomian gland changes and ocular surface grading. A moderate correlation was found between MDEQ score and LWE $\left(r_{s}=0.49, p<0.01\right)$. By contrast, a weak but significant correlation was found between MDEQ and corneal staining ( $\mathrm{rs}=0.36, \mathrm{p}<0.01)$, LWE and corneal staining $\left(r_{s}=0.35, p<0.01\right)$, meiboscore and corneal staining $\left(r_{s}\right.$ $=0.30, \mathrm{p}<0.01)$ and between MDEQ and meiboscore $\left(r_{\mathrm{s}}=0.24, \mathrm{p}<0.05\right)$. The correlation between LWE and meiboscore was also found to be weak and insignificant $\left(r_{\mathrm{s}}=0.14, \mathrm{p}=0.16\right)$. 
TABLE 1. Demographic data of subjects

\begin{tabular}{|c|c|c|c|c|}
\hline & \multirow{2}{*}{$\begin{array}{l}\text { Age } \\
\text { years }\end{array}$} & \multicolumn{2}{|c|}{ Sex } & \multirow{2}{*}{$\begin{array}{c}\text { MDEQ } \\
\text { score }\end{array}$} \\
\hline & & Male & Female & \\
\hline Non-Dry Eye (NDE) $(n=71)$ & $23.14 \pm 2.307$ & $26(36.6 \%)$ & $45(63.4 \%)$ & $7.96 \pm 3.09$ \\
\hline Dry Eye $(D E)(n=36)$ & $23.06 \pm 3.32$ & $9(25 . \%)$ & $27(75 \%)$ & $16.43 \pm 1.75$ \\
\hline
\end{tabular}

TABLE 2. Grading of conjunctiva, limbus and cornea following Efron grading scale

\begin{tabular}{cccccc}
\hline Conjunctival redness & 0 & 1 & 2 & 3 & 4 \\
\hline NDE $(n=71)$ & 28 & 36 & 7 & 0 & 0 \\
DE $(n=36)$ & 8 & 20 & 8 & 0 & 0 \\
\hline
\end{tabular}

\begin{tabular}{cccccc}
\hline Limbal redness & 0 & 1 & 2 & 3 & 4 \\
\hline NDE $(n=71)$ & 55 & 16 & 0 & 0 & 0 \\
DE $(n=36)$ & 24 & 11 & 0 & 0 & 0 \\
\hline
\end{tabular}

\begin{tabular}{cccccc}
\hline Corneal staining & 0 & 1 & 2 & 3 & 4 \\
\hline NDE $(n=71)$ & 70 & 1 & 0 & 0 & 0 \\
& & & & 0 & 0 \\
\hline
\end{tabular}

TABLE 3. LWE occurrence in upper eyelid of both groups

\begin{tabular}{ccccc}
\hline Group & $\begin{array}{c}\text { Grade 0 } \\
(<0.25)\end{array}$ & $\begin{array}{c}\text { Grade 1 } \\
(0.25-1.0)\end{array}$ & $\begin{array}{c}\text { Grade 2 } \\
(1.25-2.0)\end{array}$ & $\begin{array}{c}\text { Grade 3 } \\
(2.25-3.0)\end{array}$ \\
\hline NDE $(n=71)$ & 30 & 19 & 11 & 11 \\
DE $(n=36)$ & 2 & 1 & 13 & 20 \\
\hline
\end{tabular}


TABLE 4. Distribution of meibomian gland numbers in both groups

\begin{tabular}{cccc}
\hline Group & $\begin{array}{c}\text { Mean numbers of Meibomian } \\
\text { gland }\end{array}$ & SD value \\
\hline NDE $(\mathrm{n}=71)$ & 22.34 & 1.50 & \\
& & & 0.375 \\
$\mathrm{DE}(\mathrm{n}=36)$ & 22.50 & 1.23 & \\
\hline
\end{tabular}

TABLE 5. Meiboscore for invivo observation on meibomian gland

\begin{tabular}{ccccc}
\hline Group & Grade 0 & Grade 1 & Grade 2 & Grade 3 \\
\hline NDE $(n=71)$ & 49 & 19 & 3 & 0 \\
DE $(n=36)$ & 10 & 25 & 1 & 0 \\
\hline
\end{tabular}

\section{DISCUSSION}

This study investigated the characteristics of the meibomian gland and ocular surface in young adult living in Kuala Lumpur. The mean number of meibomian glands observed in the upper lid in this study is similar to Shirakawa et al. (2013) in Japanese populations. Craig et al. (2016) reported a significant gland dropout in Asians compared to Caucasian eyes, which was postulated to be due to the anatomical differences (single and double eyelid) between the two populations. This observation was not noted in this study because majority of the subjects $(80 \%)$ was Malay origin and has double eyelids.

The results of this study also showed higher MGDo in DE $(72.2 \%)$ than NDE subjects $(27.8 \%)$. This is in accordance with previous studies that showed MGDo is associated with DE (Feng et al. 2014; Tomlinson et al. 2011). Feng et al. (2014) examined the morphological changes of meibomian glands in DE patients in China using non-contact infrared meibography and found higher percentage of subjects with MGDo, which was around $89.2 \%$. The discrepancy was probably due to the larger age range (7-85 years). Aging is a known risk factor for MGD (Schaumberg et al. 2011). With age, meibomian gland acinar epithelial cells atrophy, exhibiting decreased lipid production and altered meibum composition with changes in neutral and polar lipid profiles (Knop et al. 2011), which in turn increased tear evaporation and caused DE.

The results of this study showed significant differences for conjunctival redness, corneal staining and
LWE between both study groups, with higher grades in DE subjects. Ishak et al. (2011) examined tarsal conjunctival redness in a healthy population in Malaysia using IER grading scale and showed mean score of $1.17 \pm 0.49$. We were unable to compare the score due to different grading scale used in both studies. However, results from both studies indicate certain level of conjunctival redness on normal healthy eyes. Conjunctival and limbal redness are associated with the defence mechanism towards environment pressure, irritant and pathogen invasion. Activating immunology responses from the vascular system in the corneal limbal produces proinflammatory intermediators, such as cytokine and chemokine which can induce tear reflex (Wei \& Asbell 2014). Prolonged exposure towards pro inflammatory intermediator can cause sensory adaptation which impairs lacrimal gland reflex and leads to apoptosis goblet cell on conjunctiva. The exposure does not cause the loss of mucin that can lead to ocular surface desiccation and cause microtrauma LWE on lid wiper area which can be stained with fluorescein and lissamine green (Efron et al. 2016).

There are few limitations of this study. Statistical analysis showed that there is a weak and insignificant association between MGDo and LWE, which was probably due to small number of subjects recruited in this study. Viet $\mathrm{Vu}$ et al. (2018) demonstrated the association between MGD and FRD (including LWE) in 449 DE patients with mean age of $62.6 \pm 15.7$ years. We were also aware that the overall functions of meibomian gland orifice were not tested in this study. Extensive 
dropout has been shown to be associated with increasing evaporative water loss from the eye (Shamzaki et al. 1995). The association between score of MGDo with functions of meibomian glands should be evaluated in future studies with larger number of subjects.

\section{CONCLUSION}

The results of this study demonstrated the differences in MGDo, LWE and ocular surface appearances between DE and NDE of the young adults. Nevertheless there was no association between MGDo and LWE. Larger number of subjects is needed to confirm these findings.

\section{ACKNOWLEDGEMENT}

This project was funded by UKM research university grant (GUP-2013-009).

\section{REFERENCES}

Ahmad, A., Ishak, B. \& Mohd Ali, B. 2017. Tear film osmolarity in young Malay after wearing contact lens for 6 months. Med. J. Malaysia 72: 28.

Arita, R., Itoh, K., Inoue, K. \& Amano, S. 2008. Non-contact infrared meibography to document age-related changes of the meibomian glands in a normal population. Ophthalmology 115: 911-915.

Brea, M.L.S., Rodríguez, N.B., González, A.M., Evans, K. \& Pena-Verdea, H. 2016. Defining the optimal region of interest for hyperemia grading in the bulbar conjunctiva. Comput. Math. Method M. 15: 3695014.

Craig, J.P., Nichols, K.K., Akpek, E.K., Caffery, B., Dua, H.S., Ki Joo, C., Liu, Z., Nelson, J.D., Nichols, J.J., Tsubota, K. \& Stapleton, F. 2017. TFOS DEWS II definition and classification report. Ocular Surf 15: 276-283.

Craig, J., Wang, M., Kim, D. \& Lee, J. 2016. Exploring the predisposition of the Asian eye to development of dry eye. Ocular Surf 14(3): 385-392.

Efron, N., Brennan, N., Morgan, P. \& Wilson, T. 2016. Lid wiper epitheliopathy. Prog. Retinal Eye Res. 53: 140-174.

Efron, N., Morgan, P.B. \& Katsara, S.S. 2011. Validation of grading scales for contact lens complications. Ophthalmic. Physiol. Opt. 21: 17-29.

Faul, F., Erdfelder, E., Lang, A.G. \& Buchner, A. 2007. G*Power 3: A flexible statistical power analysis program for the social, behavioral, and biomedical sciences. Behav. Res. Methods 39: 175-191.

Feng, Y., Gao, Z., Feng, K., Qu, H. \& Hong, J. 2014. Meibomian gland dropout in patients with dry eye disease in China. Curr. Eye Res. 39(10): 965-972.

Ishak, B., Mohd-Ali, B. \& Mohidin, N. 2011. Grading of tarsal conjunctiva of young adults in Malaysia. Clin. Exp. Optom. 94(5): 458-463.

Jamaliah, R. \& Fathilah, J. 2002. Prevalence of dry eye in University Malaya Medical Centre. Med. J. Malaysia. 57(4): 390-397.

Jester, J.V., Rife, L., Nii, D., Luttrull, J.K., Wilson, L. \& Smith, R.E. 1982. In vivo biomicroscopy and photography of meibomian glands in a rabbit model of meibomian gland dysfunction. Invest. Ophthalmol. Vis. Sci. 22: 660-667.

Jie, Y., Xu, L., Wu, Y.Y. \& Jonas, J.B. 2009. Prevalence of dry eye among adult Chinese in the Beijing Eye Study. Eye 23: 688-693
Knop, E., Knop, N., Millar, T., Obata, H. \& Sullivan, D.A. 2011. The international workshop on meibomian gland dysfunction: Report of the subcommittee on anatomy, physiology, and pathophysiology of the meibomian gland. Invest Ophthalmol. Vis. Sci. 52(4): 1938-1978.

Korb, D.R. \& Henriquez, A.S. 1980. Meibomian gland dysfunction and contact lens intolerance. J. Am. Optom. Assoc. 51(3): 243-251.

Lin, P.Y., Tsai, S.Y., Cheng, C.Y., Liu, J.H., Chou, P. \& Hsu, W.M. 2003. Prevalence of dry eye among an elderly Chinese population in Taiwan: The Shihpai Eye Study. Ophthalmology 110: 1096-1101.

McCarty, C.A., Bansal, A.K., Livingston, P.M., Stanislavsky, T.L. \& Taylor, H.R. 1998. The epidemiology of dry eye in Melbourne, Australia. Ophthalmology 105: 1114 -1119.

Mohidin, N. \& Amran, R. 2004. Fluorescein tear break-up time in Malays. JSKM 2(1): 65-73.

Mohidin, N., Bay, T.C. \& Yap, M. 2002. Non-invasive tear break up time in normal Malays. Clin. Exp. Optom. 85: 37-41.

McMonnies, C.W., Ho, A. \& Wakefield, D. 1998. Optimum dry eye classification using questionnaire responses. $A d v$. Exp. Med. Biol. 438: 835-838.

Mohammed, Z., Hajar Maidin, M.H. \& Mohd Ali, B. 2012. Lid wiper epitheliopathy in subjects with and without dry eye symptoms in Kuala Lumpur-A pilot study. Arch. Sci. 65(10): 585-590.

Mohd-Ali, B., Leong, S.F., Abdul Mutalib, H. \& Mohidin, N. 2011. Incidence of dry eye in a sample population in Kuala Lumpur. In. J. Collab. Res. Intern. Med. Public Health 3(11): 839-845.

Nicolaides, N., Santos, E.C., Smith, R.E. \& Jester, J.V. 1989. Meibomian gland dysfunction. III. Meibomian gland lipids. Invest. Ophthalmol. Vis. Sci. 30(5): 946-951.

Nelson, J.D., Shimazaki, J., Benitez-del-Castillo, J.M., Craig, J.P., McCulley, J.P., Den, S. \& Foulks, G.N. 2011. The international workshop on meibomian gland dysfunction: Report of the definition and classification subcommittee. Invest. Ophthalmol. Vis. Sci. 52: 1930-1937.

Robin, J.B., Jester, J.V., Nobe, J., Nicolaides, N. \& Smith, R.E. 1985. In vivo transillumination biomicroscopy and photography of meibomian gland dysfunction. A clinical study. Ophthalmology 92(10): 1423-1426.

Schein, O.D., Muñoz, B., Tielsch, J.M., Bandeen-Roche, K. \& West, S. 1997. Prevalence of dry eye among the elderly. Am. J. Ophthalmol. 124: 723-728.

Shimazaki, J., Sakata, M. \& Tsubota, K. 1995. Ocular surface changes and discomfort in patients with meibomian gland dysfunction. Arch. Ophthalmol. 113: 1266-1270.

Shirakawa, R., Arita, R. \& Amano, S. 2013. Meibomian gland morphology in Japanese infants, children, and adults observed using a mobile pen-shaped infrared meibography device. Am. J. Ophthalmol. 155(6): 1099-1103.

Schaumberg, D.A., Nichols, J.J., Papas, E.B., Tong, L., Uchino, M. \& Nichols, K.K. 2011. The international workshop on meibomian gland dysfunction: Report of the subcommittee on the epidemiology of, and associated risk factors for, MGD. Invest. Ophthalmol. Vis. Sci. 52: 1994-2005.

Tomlinson, A., Bron, A.J., Korb, D.R., Amano, S., Paugh, J.P., Pearce, E.I., Yee, R., Yokoi, N., Arita, R. \& Dogru, M. 2011. The international workshop on meibomian gland dysfunction: Report of the diagnosis subcommittee. Invest. Ophthalmol. Vis. Sci. 52: 2006-2042.

Uchino, M., Dogru, M., Yagi, Y., Goto, E., Tomita, M., Kon, T., Saiki, M., Matsumoto, Y., Uchino, Y., Kinoshita, S. 
\& Tsubota, K. 2006. The features of dry eye disease in a Japanese elderly population. Optom. Vis. Sci. 83: 797-802.

VietVu, C.H., Kawashima, M., Yamada, M., Suwaki, K., Uchino, M., Shigeyasu, C., Hiratsuka, Y., Yokoi, N. \& Tsubota, K. 2018. Influence of meibomian gland dysfunction and friction-related disease on the severity of dry eye. Ophthalmology 125(8): 1181-1188.

Mohamad Hanif Hajar Maidin, Bariah Mohd-Ali* \& Zainora Mohammed

Optometry \& Vision Science Programme

Faculty of Health Sciences

Universiti Kebangsaan Malaysia

Jalan Raja Muda Abdul Aziz

50300 Kuala Lumpur, Federal Territory

Malaysia
Jamaludin Mohamed

Biomedical Science Programme

Faculty of Health Sciences

Universiti Kebangsaan Malaysia

Jalan Raja Muda Abdul Aziz

50300 Kuala Lumpur, Federal Territory

Malaysia

*Corresponding author; email: bariah@ukm.edu.my

Received: 4 April 2019

Accepted: 6 December 2019 